\title{
News
}

\section{FDA chief resigns without warning}

Janice Hopkins Tanne New York

After only two months as commissioner, but 30 years at the organisation, Lester Crawford, head of the Food and Drug Administration, abruptly resigned last Friday. He sent an email message to FDA staff members saying, "It is time, at the age of 67 , to step aside."

President Bush immediately named Andrew von Eschenbach, director of the National Cancer Institute, as temporary commissioner. Dr von Eschenbach said he would continue to hold both jobs.

The New York Times this week reported an anonymous government official as claiming that Dr Crawford's resignation was related to the fact that he had not fully disclosed financial information during Senate hearings on his confirmation (Sep 24; Sect A: 1). Dr Crawford's wife, Catherine W Crawford, subsequently denied this on his behalf (New York Times, Sep 27; Sect A: 21).

Dr Crawford's resignation comes after a difficult year for the
FDA, in which it has been criticised for refusing to allow availability over the counter of the emergency contraceptive Plan B (BMJ 2005;331:596, 17 Sep) and for failing to act quickly enough on evidence indicating that the cyclo-oxygenase- 2 inhibitor rofecoxib (Vioxx) had serious side effects (Lancet 2005;365:449-51). The drug was withdrawn by its manufacturer Merck last year (BMJ 2004;329:816).

The agency has also had to contend with criticism arising from malfunctions in implanted cardiac defibrillators, a shortfall in flu vaccine because of problems with a British supplier (BMJ 2004;329:876), and delay in warning about an increased risk of suicide in children and adolescents taking antidepressants (BMJ 2004;329:702).

Susan Wood, who resigned as assistant commissioner for women's health on 31 August because of Dr Crawford's decision to delay approval of over the counter availability of Plan $\mathrm{B}$, said she was surprised by $\mathrm{Dr}$

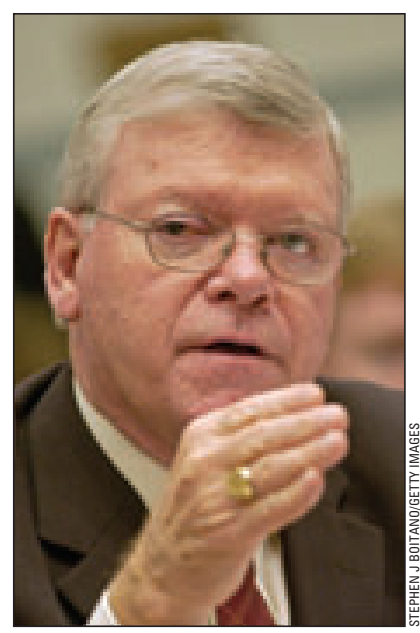

Dr Lester Crawford resigned after two months as FDA commissioner

Crawford's sudden decision. "I don't know why he left," she said. "It might have to do with issues around scientific decision making at the agency."

She said Dr Crawford's resignation would be unsettling for people at the agency. After she resigned the agency first named a male veterinarian to head the women's health office and later named Theresa Toigo, head of the FDA's Office of Special Health Issues, as temporary head of the women's office.

"The new acting commissioner has a very strong scientific background, so perhaps we can hope he will take another look at Plan B," Dr Wood added.

Dr Crawford, a veterinarian and expert in pharmacology and food safety, had finally been named commissioner in July, after two senators released a "hold" on his nomination when they were promised a decision on Plan B by 1 September. Instead Dr Crawford postponed the decision (BMJ 2005;331:472).

Senator Chuck Grassley of Iowa (Republican), chairman of the Senate committee which oversees the FDA, welcomed the change, saying, "In recent years the FDA has demonstrated a too cosy relationship with the pharmaceutical industry."

\section{Writers join experts to campaign to save NHS from privatisation}

Sophie Arie London

Some of Britain's leading writers have joined a growing campaign to stop government plans to extend the privatisation of the NHS in certain areas.

The poet laureate, Andrew Motion, and the authors Philip Pullman, Nick Hornby, and Clare Tomalin are among several unexpected public figures joining a campaign to "keep our NHS public."

They joined over 30 experts on public health, including the former Labour health secretary Frank Dobson, former BMA chairman Sandy Macara, and former chief medical officer for Scotland Mac Armstrong, to sign a campaign statement published as a letter in the Guardian newspaper (Sep 24: 31).

"The NHS stands at a crossroads. For nearly 60 years, Britain has enjoyed a National Health Service that strives to be comprehensive, accessible and high value for money," the statement said. "Now, government reforms threaten both the ethos of the NHS and the planned and equitable way in which it delivers care to patients."

The greatest concern is that the government's plans to contract private sector companies to provide NHS services, including primary care and surgery, will create a climate of competition in the service. That could mean that in business terms some patients and some illnesses are favoured as more profitable than others.

Increasing numbers of staff at public hospitals will defect to the private sector, while a growth in paperwork will eat into already scarce health funding, the campaigners fear.

"There is no evidence that these reforms will improve the health service," warn the campaigners. "Forced market competition will break up the NHS as a collaborating network. There will be winners and losers, with some units and even entire hospitals having to close. We are already seeing job losses and bed closures in NHS hospitals."

At this week's Labour party conference in Brighton the public service union Unison called for the suspension of "any further expansion of the role of the private sector into the NHS."

The secretary of state for health, Patricia Hewitt, defends the government's plans to contract operations out to the private sector as a way to reduce waiting lists. She has said she expects up to 500000 operations a year to be carried out this way once the privately run treatment centres are up and running. 